Full length article

\title{
Framing CSR fit: How corporate social responsibility activities are covered by news media
}

\author{
Katharina Lunenberg, Jordy F. Gosselt*, Menno D.T. De Jong \\ University of Twente, Department of Communication Studies, The Netherlands
}

\section{A R T I C L E I N F O}

\section{Article history:}

Received 18 August 2015

Received in revised form

23 November 2015

Accepted 23 November 2015

Available online 26 October 2016

\section{Keywords:}

Corporate social responsibility

CSR fit

Media coverage

Framing

Tone

\begin{abstract}
A B S T R A C T
This research provides a basis for understanding how the contents of media coverage about CSR activities relates to the fit between these CSR activities and the organizations' core activities. In two steps, 513 news articles about organizations' CSR activities were analyzed. First, an expert review determined the fit between the CSR initiatives presented in the news articles and the core business of the organizations pursuing these initiatives. Second, a quantitative content analysis measured tone and framing of the news articles. The results reveal that while CSR fit does not influence tone, it does partly impact the framing of the media coverage, as CSR fit leads to a positive framing of organizations and their CSR activities. However, vice versa, CSR misfit does not necessarily lead to a negative representation of organizations and their CSR in the media coverage. In order to maximally benefit from their CSR activities and achieve optimal media coverage, organizations are advised to not only engage in CSR, but seek to implement initiatives that are well integrated into their core business.
\end{abstract}

(c) 2016 Elsevier Inc. All rights reserved.

\section{Introduction}

In today's society and business world, corporate social responsibility (CSR) is a highly relevant topic. By communicating their CSR activities to the public, many companies try to improve their reputation, consumer loyalty, and consumer trust (Stanaland, Lwin, \& Murphy, 2011) or attract high potential employees (Berger, Cunningham, \& Drumwright, 2007). While the literature offers numerous definitions, Aguinis and Glavas (2012) specify CSR as "context-specific organizational actions and policies that take into account stakeholders' expectations and the triple bottom line of economic, social and environmental performance" (Aguinis \& Glavas, 2012, p. 933). CSR activities can be distinguished from other organizational activities by two characteristics: they benefit society or general interest, and they are not obligated by law (De Jong \& Van der Meer, in press).

In the literature on the effects of CSR on stakeholders much attention is given to the concept of CSR fit. CSR fit involves the similarity between characteristics of an organization and characteristics of its CSR activities (Becker-Olsen, Cudmore, \& Hill, 2006; Du, Bhattacharya, \& Sen, 2010). Although there are some studies suggesting the opposite, it is generally assumed that CSR fit positively influences the effects of CSR activities on external stakeholders, mostly consumers (De Jong \& Van der Meer, in press). An important aspect that has so far been underexposed in the literature about CSR fit is the role of news media. Much

\footnotetext{
* Corresponding author at: University of Twente, Faculty of Behavioral Sciences, Department of Communication Studies, P.O. Box 217, 7500 AE Enschede, The Netherlands.

E-mail address: j.f.gosselt@utwente.nl (J.F. Gosselt).
} 
of the information stakeholders receive about CSR activities of organizations will be mediated by news media, which may amplify, interpret, and modify the CSR information provided by organizations. As independent monitors of organizations' activities (Zhang \& Swanson, 2006), news media can be expected to take a critical perspective on organizations' CSR activities. The research reported in this article fills this gap in the literature. We analyzed the relationship between CSR fit and media coverage in two steps: an expert review determining the fit between organizations and their CSR activities, and a content analysis of the media coverage of those activities. Our research question was: What is the impact of CSR fit on the media coverage about CSR activities?

\section{Theoretical framework}

\subsection{Conceptualizing CSR fit}

Yuan, Bao, and Verbeke (2011) distinguish three types of CSR fit: external consistency (the fit with stakeholder demands), coherence (the fit with other CSR activities), and internal consistency (the fit with the organization's core activities). In this study, we focus on the internal consistency. Based on existing literature, Yuan et al. (2011) developed a conceptual framework with seven patterns of CSR initiative adoption. The purpose of this framework is to identify the fit between an organization's core business and CSR practices. While the first four patterns (born CSR, patching, thickening, and positioning) represent degrees of internal consistency and can be perceived as an ordinal scale, the last three patterns (relabeling, trimming, and cooperating) focus more on specific ways to integrate CSR initiatives. These three patterns are redundant in the context of this research, as they can be assigned to any of the first four patterns: The recognition of organizational activities as CSR (relabeling), the elimination of existing CSR initiatives (trimming), and inter-organizational CSR alliances (cooperating) can all be pursued in such ways that they belong to born CSR, patching, thickening, or positioning.

Looking in more detail at the first four patterns it can be stated that born CSR describes the strongest degree of internal consistency. Organizations applying this pattern have incorporated CSR as a crucial part of their operations showing a high commitment in terms of resources towards CSR, so that their "core business and CSR routines are indistinguishable from each other" (Yuan et al., 2011; p. 80). Patching can be seen as a medium degree of internal consistency, with CSR codetermining organizational operations and strongly interacting with current organizational routines, thereby influencing future organizational practices. Such integration of CSR often reflects in the institutionalization of core values driving CSR and the implementation of CSR values at the operational level. When CSR initiatives are built upon core business routines and benefit from their strengths, this is referred to as thickening. In these cases, changes in the core business routines do influence the organization's CSR; however, conversely, changes in the organization's CSR do not influence the business' core. Finally, positioning involves the creation of new CSR routines as independent peripheral practices not influencing or being influenced by the core business activities. To summarize, born CSR, patching, and thickening all describe a certain degree of fit between CSR initiatives and an organization's core business, while positioning defines a CSR initiative as a peripheral independent practice. Based upon these conceptualizations, all CSR initiatives categorized as born CSR, patching, or thickening are defined as having a CSR fit, while all CSR initiatives categorized as positioning are defined as having a CSR misfit. In this paper, CSR fit is thus defined as any degree of consistency between an organization's CSR activities and its core business, while CSR misfit is defined as the absence of consistency between an organization's CSR activities and its core business.

\subsection{Media coverage: tone and framing}

As independent monitors of organizations' activities, representing the public's interest, news media codetermine the public discourse on CSR (Wang, 2007; Zhang \& Swanson, 2006). Two basic concepts central to the presentation of topics and issues in the media are tone and framing.

While traditional agenda setting hypothesizes that the emphasis placed on certain aspects in media coverage influences public perception, second-level or attribute agenda setting in addition focuses on the tone of news coverage (Hester \& Gibson, 2003). Most commonly, a distinction is made between a positive, neutral, and negative tone (Deephouse, 2000; McCombs \& Ghanem, 2001). In general, past research indicates that tone in media coverage impacts the public perception of the topic of interest (De Vreese \& Boomgaarden, 2006; Kim, Caravllo, \& Cooksey, 2007). Since media codetermine the public discourse on CSR, it is relevant to explore how journalists evaluate organizations and their CSR activities. Using a positive, neutral, or negative tone within their coverage, journalists may influence the way the public perceives organizations and their CSR activities. For example, in their investigation of the coverage of CSR in the Financial Times between 1988 and 2003 , Buhr and Grafström (2007) found that the overall tone of media coverage on CSR was positive, with the intention to convince organizations to participate more in CSR activities.

Besides tone, framing is a central media mechanism in forming the public perception of issues (Miller \& Riechert, 2001; Price, Tewksbury, \& Powers, 1997). Framing involves generating a social construction of phenomena by "select[ing] some aspects of a perceived reality and [making] them more salient in a communicating text, in such a way as to promote a particular problem definition, causal interpretation, moral evaluation, and/or treatment recommendation" (Entman, 1993; p. 52). By selecting and highlighting certain aspects of information, frames make a piece of information more noticeable, 
meaningful, or memorable to audiences (Entman, 1993; p. 53). Consequently, frames define problems, diagnose causes, make moral judgments, and suggest remedies.

\subsection{CSR fit and media coverage}

CSR fit can be expected to influence media coverage for two reasons: the impact of CSR fit on public perception, and the prevalence of the concept of CSR fit in journalists' perceptions. First, it is reasonable to apply observations about the relationship between CSR fit and public perception to this specific context, because the "public opinion is part of the process by which journalists [...] develop and crystallize meaning" (Gamson \& Modigliani, 1989). Earlier research indicates that CSR fit impacts people's perceptions of organizations and their CSR activities (Becker-Olsen et al., 2006; Bloom, Hoeffler, Keller, \& Meza, 2006; Drumwright, 1996; Ellen, Mohr, \& Webb, 2000; Elving, 2013). As media professionals are individuals belonging to the public, they can be expected to be influenced by the same processes that are relevant to the public perception of CSR fit.

Second, in their research, Tench, Bowd, and Jones (2007) interviewed 63 media professionals to investigate what CSR means to them. The media professionals appeared to see CSR fit as a key component of CSR. Specifically, they focused strongly on the way organizations run their business. A high CSR fit means that CSR activities are deeply integrated into the organizations' core, and therefore also determine how the organization operates (Yuan et al., 2011). In addition, Tench et al. (2007) found a willingness of journalists to cover those points journalists see as the key attributes of CSR-CSR fit being one of them. Furthermore, based on questionnaires and face-to-face interviews, Tench et al. (2007) identified five distinct frames of how organizations are perceived by journalists concerning their CSR activities, ranging from a strongly negative perception (conformist) to a strongly positive perception (strategic idealist). Organizations categorized as conformists are described to pursue CSR in order to follow others. They only see CSR activities as a cost, not comprehending the true benefits of such activities. Cynics are perceived to adopt CSR due to economic self-interest. They also only see CSR as cost, reveal low engagement in CSR, and the organizational change practiced in this context is rather perceptual than substantial. Realists are seen as organizations actively engaging in CSR thereby accepting that these activities have limitations and involve self-interest. They see the costs of CSR as necessary for improving themselves and triggering transformation for the better. Optimists strongly focus on the benefits of CSR and deemphasize potential negative consequences. Their CSR activities may be driven by a variety of intentions such as their community, environmental aspects, and economic self-interest. They actively engage in CSR, embrace change, and perceive CSR as investment rather than as cost. Strategic idealists are organizations trying to maximize the benefits and minimize the negative consequences of CSR. They also actively engage in CSR and perceive it as investment, but most importantly, they pursue CSR for its own sake - as a force for good. These five orientations highlight different aspects of how an organization is perceived to pursue CSR and therefore coincide with the concept of framing. Since journalists have a need to preserve their existing knowledge and attitudes (Donsbach, 2004), one can expect that they will incorporate such orientations into media coverage.

Past research into the effects of CSR fit on public perception is contradictory, with most studies pledging for the advantages of a high fit (e.g., Becker-Olsen et al., 2006; Elving, 2013) and some studies pledging for the advantages of a low fit (Bloom et al., 2006; Drumwright, 1996; Ellen et al., 2000) (cf. De Jong \& Van der Meer, in press for an overview). Explanations for the advantages of a high fit involve that such activities require less cognitive elaboration, and therefore raise fewer critical questions (Becker-Olsen et al., 2006; Du et al., 2010; Elving, 2013), and may be perceived to be more structurally embedded within the organization (De Jong \& Van der Meer, in press). An explanation for the advantage of a low fit is that the CSR activities may be perceived to reflect a more deliberate and larger effort (Drumwright, 1996; Ellen et al., 2000).

In sum, as past research indicates that CSR fit is an important factor in stakeholders' perceptions of CSR activities, one can assume that this will also be the case for journalists. In this study, we therefore propose that the degree of CSR fit affects the selection of attributes assigned to the organization and its CSR (framing), leading to a positive, neutral, or negative tone in the media coverage (Deephouse, 2000; McCombs \& Ghanem, 2001). Consequently, we aim to answer the following specific sub questions:

Sub question 1: What is the impact of CSR fit on holistic CSR frames?

Sub question 2: What is the impact of CSR fit on specific CSR frame elements?

Sub question 3: What is the impact of CSR fit on the tone of media coverage?

\section{Method}

To investigate the effects of CSR fit on media coverage, the study was conducted in two steps. First, we reviewed the CSR initiatives presented in 513 news articles in order to assess the degree of CSR fit. Second, a quantitative content analysis of these news articles measured the framing and tone of the media coverage. Then, the data from both steps were compared to determine the relationship between CSR fit and media coverage.

\subsection{Corpus of news articles}

Via the LexisNexis database, all English written news articles published between February 22nd and May 23rd, 2013 were selected that met the following inclusion criteria: (1) the search term 'corporate social responsibility' or 'CSR'; (2) 
two additional index terms ('company activities' and 'management'); and (3) the source of the material (newspapers and magazines). Regarding the latter, these two sources were selected because they are expected to reflect the public discourse on CSR at two levels - people actively interested in topics such as CSR (magazines), and society at large (newspapers). Further, the index terms 'company activities' and 'management' were added to increase the likelihood of inclusion of news articles that describe specific organizations' CSR activities. These inclusion criteria resulted in 2455 news articles.

To draw a suitable sample of this total, it was decided to only include the news articles that described a single company pursuing one or more CSR initiatives, while news articles reporting about CSR in general, reporting about several companies, or not describing specific CSR initiatives were excluded from the sample. Furthermore, all news articles that concerned press releases (e.g., written in first person perspective) and repetitions of the same news article were excluded from the sample. This resulted in a final sample of 513 news articles, ranging from short descriptions to extensive reports on an organization's CSR initiatives. On average, the news articles contained approximately 378 words $(\mathrm{M}=378.42, \mathrm{SD}=192.12)$, and came from 39 different countries with India (24.8\%), Nigeria (9.6\%), Pakistan (9.2\%), and Sri Lanka (5.7\%) constituting the biggest portion of the sample.

\subsection{Review of CSR fit}

To determine the degree of CSR fit regarding the CSR activities described in the 513 news articles, all of these described CSR activities were reviewed by one of the authors as well as an external researcher experienced in the field of CSR research. First, all CSR initiatives presented were listed in a table and grouped according to the organizations behind them. Second, each company's website was analyzed to retrieve a description of the organizations' core business(es) and these descriptions were inserted in the table, next to the CSR initiatives. Then, based on the definition of the different degrees of CSR fit (born CSR, patching, thickening, and positioning), the author as well as the external researcher judged the fit between the CSR initiative and the organizations' core activities. First, both reviewers evaluated 20 initiatives together, in order to reach agreement on their categorization. Next, the reviewers independently evaluated the fit between the CSR initiatives and the core activities of the organization. In those cases where no agreement in the evaluation of CSR fit could be achieved, a third external researcher, also experienced in the field of CSR research, was consulted. Based on his evaluations one of the four categories was assigned to the discrepant cases. After discussion of discrepancies and the adaption of the evaluations, a Cohen's kappa of 0.92 was achieved.

\subsection{Content analysis media coverage}

All news articles were coded on the basis of a code manual consisting of three categories: (1) background information of the organization and the news article; (2) tone and holistic frame use; and (3) specific elements of the CSR frames. See Table 1 for the code manual.

The first part of the code manual included descriptive information of the material, regarding the organization described (including country of origin and industry of organization) and the news article (name of newspaper/magazine, country of newspaper/magazine, number of words, and number of CSR initiatives described).

The second part of the code manual concerned the media's description of the CSR initiatives and the organization. Here, it was assessed whether the overall tone of the news articles was positive, neutral, or negative. Furthermore, the CSR frames as defined by Tench et al. (2007) - conformist, cynic, realist, optimist, and strategic idealist - were used as codes.

Third, these CSR frames were split into specific elements that were coded separately. These elements were coded based on the definitions of the five CSR frames by Tench et al. (2007). First, for each frame, a specific intention (using CSR for its own sake, stakeholder pressure, self-interest, following others to not be left behind) with which an organization is perceived to pursue its CSR activities could be identified. Organizations 'using CSR for its own sake' were described, for example, to implement a "welcome initiative [that] has the potential to change for the better the lot of many poor but meritorious students", making "a humanitarian gesture" or "starting a socially responsible business [...] to help fill the gap in the medical system”. Furthermore, some organizations were depicted to pursue CSR due to 'stakeholder pressure' such as a supermarket chain "giving back to its stakeholders in a big way" by distributing profits to employees and shareholders or an electricity supplier developing "a [...] value creation model that places greater focus on building strong ties with all its key stakeholder groups". Organizational 'self-interest' in CSR was deemed to be used as frame element in the articles when any benefit for the organization itself was highlighted, for example, a retrofit helping a company to "balance its commitments to costeffective service and environmental responsibility at a cost that's 30 percent less than other alternatives". Moreover, some organizations were described to pursue CSR 'following other organizations in order to not be left behind' such as a catering company which "arranged to have all its meat products tested to show that there are no traces of horse meat [...] following other company's having their products tested". All these four intentions were added to the code manual as separate codes. Second, in each of the five CSR frames, some form of organizational change caused by the implementation of the CSR initiatives was described. This organizational change can be identified to take three different forms. First, 'perceptual change' - how the organization is perceived to change (rather than changing its core operations) - was identified when the articles described an organization to pursue its CSR initiatives in such a way that the perception of these activities was central. Examples for this frame element include an airline giving a wheelchair to a disabled girl during "an event organized by the Association of People with Disability" or a water and energy supplier receiving "a large number of visitors including delegations of students 
Table 1

Code Manual.

\begin{tabular}{|c|c|c|c|c|}
\hline Category & Sub-category & Definition & Codes & Kappa \\
\hline \multirow[t]{2}{*}{ (1) Descriptive Information } & Organization & $\begin{array}{l}\text { Descriptive information about the } \\
\text { organization presented in the article }\end{array}$ & $\begin{array}{l}\text { - Country of organization } \\
\text { - Industry of organization }\end{array}$ & 0.756 \\
\hline & Article & $\begin{array}{l}\text { Descriptive information about the } \\
\text { newspaper/magazine and the article }\end{array}$ & $\begin{aligned} \text { - Name of } \\
\text { newspaper/magazine } \\
\text { - Country of } \\
\text { newspaper/magazine } \\
\text { - Number of words } \\
\text { - Number of CSR } \\
\text { initiatives }\end{aligned}$ & 1.000 \\
\hline \multirow[t]{2}{*}{ (2) Presentation } & Tone & $\begin{array}{l}\text { Overall tone of the article } \\
\text { - Positive } \\
\text { - Neutral } \\
\text { - Negative }\end{array}$ & 0.733 & \\
\hline & $\begin{array}{l}\text { Holistic CSR } \\
\text { Frames }\end{array}$ & $\begin{array}{l}\text { Holistic CSR frames as defined by Tench } \\
\text { et al. (2007) }\end{array}$ & $\begin{array}{l}\text { - Conformist } \\
\text { - Cynic } \\
\text { - Realist } \\
\text { - Optimist } \\
\text { - Strategic idealist }\end{array}$ & 0.711 \\
\hline \multirow[t]{5}{*}{ (3) CSR Frame Elements } & Intention & $\begin{array}{l}\text { The reason why an organization } \\
\text { participates in CSR }\end{array}$ & $\begin{array}{l}\text { - Following other } \\
\text { organizations } \\
\text { - Self-interest } \\
\text { - Stakeholder pressure } \\
\text { - Using CSR for its own } \\
\text { sake } \\
\text { - Not specified }\end{array}$ & 0.852 \\
\hline & Change & $\begin{array}{l}\text { Organizational change with regard to the } \\
\text { implementation of the CSR initiatives }\end{array}$ & $\begin{array}{l}\text { - Perceptual change } \\
\text { - Incremental change } \\
\text { - Substantial change } \\
\text { - Not specified }\end{array}$ & 0.715 \\
\hline & $\begin{array}{l}\text { Cost vs. } \\
\text { investment }\end{array}$ & $\begin{array}{l}\text { Whether the organization perceives CSR } \\
\text { initiatives as cost or investment }\end{array}$ & $\begin{array}{l}\text { - Cost } \\
\text { - Cost necessary to } \\
\text { achieve improvement } \\
\text { - Investment } \\
\text { - Not specified }\end{array}$ & 0.758 \\
\hline & Engagement & $\begin{array}{l}\text { Degree of organizational engagement in } \\
\text { the CSR initiatives }\end{array}$ & $\begin{array}{l}\text { - Low engagement } \\
\text { - Active engagement } \\
\text { - Not specified }\end{array}$ & 0.736 \\
\hline & Judgment & Overall judgment of the CSR initiatives & $\begin{array}{l}\text { - Positive } \\
\text { - Neutral } \\
\text { - Negative }\end{array}$ & 0.735 \\
\hline
\end{tabular}

from various schools and colleges across Qatar at the QP Environment Fair 2013" in order to discuss CSR topics with them. Second, 'incremental change' - the organization changes step by step - was deemed to be applied for example in an article stating that "the scope of CSR activities is steadily getting wider, ranging from pro bono work [... to to charity activities." Third, 'substantial change' - the organization changes deeply as its core is involved - was reflected in news articles describing CSR to change the organization itself in a profound way, for example depicting "CSR initiatives [as] a way for companies to improve and develop [...] the organization" and "recognizing every employee as a powerful agent of positive change". If no form of these changes was prevalent, it was coded as 'not specified.' Third, each CSR frame as described by Tench et al. (2007) indicates whether the organization perceives CSR as cost or investment. The organizations were coded to perceive CSR simply as 'cost', as 'cost necessary to achieve improvement,' or as 'investment'. In those articles where CSR was mainly described as 'cost' it was very much focused on the amount or percentage of money paid such as an organization launching "a five-year, \$3 million program to support alumni activities and provide small grants". When next to the costs also the gained improvements where highlighted, the code 'cost necessary for improvement' was applied. Examples are a financial group giving "a donation, which will be spent to improve the heating systems of [a] facility [for disabled people]" or "money [...] spent to improve the educational environment for children of poor families". Moreover, organizations were also framed to perceive CSR as 'investment' such as a pharmaceutical company "building healthier communities through social investments 
and community engagement initiatives" or a mining corporation which noticed the "need to invest significantly in sport and many other social engagements". Fourth, the five CSR frames indicate whether the organizations are perceived to show low or active engagement in their CSR. While 'low engagement' was reflected in the articles by organizations that pursue CSR rather superficially such as "a railway giant [which] certainly has room to give more”, 'active engagement' was stressed by phrases such as "continuously engage in value-adding partnerships" or "the most significant and enduring change occurs when team members are actively engaged". Finally, all five CSR frames deliver a judgment on the organization and its CSR. While the strategic idealist and optimist frame deliver a 'positive' judgment on the organization and its CSR, the realist frame delivers a 'neutral' and the cynic and conformist frame deliver a 'negative' judgment.

In order to validate the instrument, two coders independently coded $10 \%$ of the sample. After three rounds of coding and several minor adaptions, the final version of the code manual was validated with each categorical code reaching a Cohen's kappa of at least 0.70 (see Table 1 ).

\section{Results}

\subsection{Descriptive statistics}

Descriptive statistics reveal that most CSR initiatives presented in the 513 news articles are categorized as fit (58.7\%) rather than misfit (41.3\%). Furthermore, the majority of the articles (73.7\%) have a positive tone, 20.5\% of the news articles have a neutral tone, and 5.8\% have a negative tone. Looking at the relative composition of the different CSR frames, it becomes clear that the two most negative frames - conformist and cynic (1.0\% and 3.1\% respectively) - are least present within the news articles, while the second most positive frame - optimist (38.4\%) - is most frequently used, followed by realist (18.5\%) and strategic idealist (14.6\%). In addition, one also has to consider that in nearly one quarter of the cases (24.4\%), it was not possible to assign a specific CSR frame to a news article.

In the following sections the impact of CSR fit on tone, holistic CSR frames, and CSR frame elements will be discussed. All significant correlations have been controlled for underlying factors such as industry, type of CSR initiative or country of origin in order to ensure that none of them would impede the relationships between CSR fit and the dependent variables.

\subsection{Impact of CSR fit on tone}

Before conducting a binary logistic regression analysis on the predictive effects of CSR fit on the three categories of tone (positive, neutral, and negative), Pearson's chi-square test was used to determine the correlations between these categorical variables. Since a significant correlation could only be identified for CSR fit and neutral tone $\left(\chi^{2}=6.655\right.$, p < 0.05), a binary logistic regression was performed to ascertain the effects of CSR fit on the likelihood that a news article has a neutral tone. The logistic regression model is statistically significant $\left(\chi^{2}(1)=6.572, p<0.05\right.$; Nagelkerke $R^{2}=2 \%, 79.5 \%$ of cases classified) showing that CSR fit significantly predicts neutral tone (see Table 2 ).

\subsection{Impact of CSR fit on holistic CSR frames}

Pearson's chi-square tests or Fisher's exact tests were conducted to identify the correlations between CSR fit and six different CSR frames (conformist, cynic, realist, optimist, strategic idealist, and none). Significant correlations could be identified between CSR fit and three CSR frames (realist: $\chi^{2}=4.568, \mathrm{p}<0.05$; strategic idealist: $\chi^{2}=12.613, \mathrm{p}<0.001$; none: $\left.\chi^{2}=21.777, \mathrm{p}<0.001\right)$. For each of these correlated CSR frames, a binary logistic regression was conducted, which revealed that CSR fit significantly predicts all three CSR frames: realist $\left(\chi^{2}(1)=4.68, \mathrm{p}<0.05\right.$; Nagelkerke $\mathrm{R}^{2}=1.5 \%, 81.5 \%$ of cases correctly classified); strategic idealist $\left(\chi^{2}(1)=13.441, \mathrm{p}<0.001\right.$; Nagelkerke $\mathrm{R}^{2}=4.6 \%, 85.4 \%$ of cases correctly classified); and none $\left(\chi^{2}(1)=21.532, \mathrm{p}<0.001\right.$; Nagelkerke $\mathrm{R}^{2}=6.1 \%, 75.6 \%$ of cases correctly classified $)$.

These results show that CSR fit increases the likelihood that a realist or strategic idealist frame is applied in the news article. News articles describing these types of organizations deliver a neutral judgment on the CSR initiatives, such as in the case of a realist frame in an article on a logistic company which starts with a description of the company's president point of view:

"More and more companies are realizing that the creation of modern CSR programs can improve employee morale and corporate culture, as well as retain and attract skilled staff. This is according to [company president's name] of [company name], who said that modern CSR programs have moved beyond simply aligning a company's business strategy and engagement with key stakeholder groups."

An example of a strategic realist frame would be a food retailer

"that with the support of [its] customers has reduced the number of plastic shopping bags from its stores nationally by more than five billion since 2007. This reduction is a part of one of [company name]'s five principles of corporate social responsibility, and emphasizes its commitment to waste diversion. In 2007, [company name] became one of the first retailers to introduce bagless stores. [...] To date, [company name] has seven stores across Canada where plastic shopping bags are not available." 
Table 2

The Predictive Effects of Internal CSR Fit.

\begin{tabular}{|c|c|c|c|}
\hline Dependent Variable B(SE) Wald Odds Ratio & $\mathrm{B}(\mathrm{SE})$ & Wald & Odds Ratio \\
\hline $\begin{array}{l}\text { Tone } \\
\text { Neutral* }^{*}\end{array}$ & 0.311 & 1.836 & 1.365 \\
\hline $\begin{array}{l}\text { CSR Frames } \\
\text { No Frame*** } \\
\text { Realist } * \\
\text { Strategic Idealist*** }\end{array}$ & $\begin{array}{l}0.683 \\
-0.384 \\
-0.582\end{array}$ & $\begin{array}{l}9.221 \\
2.405 \\
5.682\end{array}$ & $\begin{array}{l}1.979 \\
0.681 \\
0.559\end{array}$ \\
\hline $\begin{array}{l}\text { Intention } \\
\text { Self-Interest }{ }^{* * *} \\
\text { Stakeholder Pressure }{ }^{* * *}\end{array}$ & $\begin{array}{l}-0.943 \\
-2.699\end{array}$ & $\begin{array}{l}9.449 \\
6.843\end{array}$ & $\begin{array}{l}0.389 \\
0.067\end{array}$ \\
\hline $\begin{array}{l}\text { Change } \\
\text { Not Specified }{ }^{* * *} \\
\text { Substantial Change*** }\end{array}$ & $\begin{array}{l}-2.781 \\
-1.354\end{array}$ & $\begin{array}{l}7.221 \\
16.471\end{array}$ & $\begin{array}{l}0.062 \\
0.258\end{array}$ \\
\hline $\begin{array}{l}\text { Cost vs Investment } \\
\text { Not Specified*** } \\
\text { CSR as Cost** } \\
\text { CSR as Investment }\end{array}$ & $\begin{array}{l}1.579 \\
1.052 \\
-0.434\end{array}$ & $\begin{array}{l}23.444 \\
4.230 \\
3.999\end{array}$ & $\begin{array}{l}0.206 \\
2.864 \\
0.648\end{array}$ \\
\hline $\begin{array}{l}\text { Engagement } \\
\text { Not Specified } \\
\text { Active Engagement*** }\end{array}$ & $\begin{array}{l}-0.533 \\
-0.551\end{array}$ & $\begin{array}{l}5.864 \\
6.974\end{array}$ & $\begin{array}{l}0.587 \\
0.576\end{array}$ \\
\hline $\begin{array}{l}\text { Judgment } \\
\text { Not Specified } \\
\text { Positive*** } \\
\text { Negative }^{* *}\end{array}$ & $\begin{array}{l}0.661 \\
-0.314 \\
-1.815\end{array}$ & $\begin{array}{l}6.820 \\
2.597 \\
2.899\end{array}$ & $\begin{array}{l}1.936 \\
0.731 \\
0.163\end{array}$ \\
\hline
\end{tabular}

Predictor statistically significant at ${ }^{*} \mathrm{p}<0.05,{ }^{* *} \mathrm{p}<0.01,{ }^{* * *} \mathrm{p}<0.001$.

In the course of the news article, the food retailer is clearly depicted in a positive way as it is described to demonstrate "great leadership in helping Canadians make more eco-friendly choices in their shopping bags, home energy use and education". Finally, CSR fit decreases the likelihood that no frame is applied in the news articles.

\subsection{Impact of CSR fit on CSR frame elements}

Since the CSR frames were measured in two different ways (as overall coherent concepts and as single CSR frame elements which were coded separately), the separate elements of the CSR frames were also considered in the analysis (for examples of the coded CSR frame elements see paragraph 2.3). First, Pearson's chi-square tests or Fisher's exact tests were conducted to identify the correlations between CSR fit and the CSR frame elements (intention, cost vs. investment, engagement, and judgment). For those combinations with a significant relationship, a binary logistic regression was conducted.

After controlling for underlying influences, twelve significant predictive effects of CSR fit on the CSR frame elements remain (see Table 2). First, CSR fit increases the likelihood that 'self-interest' $\left(\chi^{2}(5)=39.935, p<0.001\right.$; Nagelkerke $R^{2}=12.8 \%$, $84.4 \%$ of cases correctly classified $)$ and 'stakeholder pressure' $\left(\chi^{2}(8)=55.645, \mathrm{p}<0.001\right.$; Nagelkerke $\mathrm{R}^{2}=27.1 \%, 94.5 \%$ of cases correctly classified) are described as an organization's intention to pursue its CSR initiatives. Second, looking at the CSR frame element 'change,' it becomes clear that CSR fit increases the likelihood that organizational change is not specified within a news article $\left(\chi^{2}(11)=51.617, \mathrm{p}<0.001\right.$; Nagelkerke $\mathrm{R}^{2}=25.2 \%, 94.7 \%$ of cases correctly classified $)$ or described as substantial change $\left(\chi^{2}(9)=109.486, p<0.001\right.$; Nagelkerke $R^{2}=30.4 \%, 80.5 \%$ of cases correctly classified $)$. Third, looking at the CSR frame element 'cost vs. investment,' three predictive effects of CSR fit can be observed. On the one hand, CSR fit increases the likelihood that an organization is described as perceiving its CSR initiatives as an investment $\left(\chi^{2}(5)=47.006, p<0.001\right.$; Nagelkerke $\mathrm{R}^{2}=12.3 \%, 70.2 \%$ of cases correctly classified) and that the organization's perception is not $\operatorname{specified}\left(\mathrm{x}^{2}(4)=97.512, \mathrm{p}<0.001\right.$; Nagelkerke $\mathrm{R}^{2}=27.3 \%, 80.9 \%$ of cases correctly classified). On the other hand, CSR fit decreases the likelihood that an organization is described as perceiving its CSR initiatives as a cost $\left(\chi^{2}(2)=9.324, \mathrm{p}<0.01\right.$; Nagelkerke $\mathrm{R}^{2}=6.6 \%, 96.3 \%$ of cases correctly classified). Fourth, CSR fit increases the likelihood that an organization is described as 'actively engaging' in its CSR initiatives $\left(\chi^{2}(7)=92.285, \mathrm{p}<0.001\right.$; Nagelkerke $\mathrm{R}^{2}=22.3 \%, 67.6 \%$ of cases correctly classified) and that an organization's engagement is not specified $\left(\chi^{2}(6)=44.934, p<0.001\right.$; Nagelkerke $R^{2}=11.8 \%, 70.4 \%$ of cases correctly classified). Finally, CSR fit decreases the likelihood that there is no specific 'judgment' about the organization and its CSR initiatives delivered within the news articles $\left(\chi^{2}(2)=19.926, \mathrm{p}<0.001\right.$; Nagelkerke $\mathrm{R}^{2}=6.6 \%, 84.8 \%$ of cases correctly classified $)$. This means that in case of a fit of a CSR initiative, it is more likely that a news article delivers a judgment regarding the organization and its activities. However, whether this judgment is positive $\left(\chi^{2}(3)=25.958, \mathrm{p}<0.001\right.$; Nagelkerke $\mathrm{R}^{2}=6.8 \%, 65.9 \%$ of cases correctly classified) or negative $\left(\chi^{2}(3)=13.757, \mathrm{p}<0.01\right.$; Nagelkerke $\mathrm{R}^{2}=12.6 \%, 97.5 \%$ of cases correctly classified ) does not differ statistically. 


\section{Discussion}

\subsection{Main findings and conclusions}

This research provides a basis for understanding how the fit between organizations' CSR activities and their core activities relates to the contents of media coverage. In line with earlier research into the effects of CSR fit on stakeholders (e.g., BeckerOlsen et al., 2006; Bloom et al., 2006; Drumwright, 1996; Ellen et al., 2000; Elving, 2013), it was expected that CSR fit would influence the way media describe organizations and their CSR activities.

The results of this study partly confirm this expectation. First, and in line with Buhr and Grafström's (2007) findings, most news articles about organizations and their CSR activities had a positive tone. CSR fit is found to be predictive of a neutral tone, and when CSR initiatives fit organizations' core business, the likelihood increases that the most positive frame possible (strategic idealist) is used in news articles. Based on these observations, one can conclude that CSR fit positively impacts media coverage with regard to framing. CSR misfit, however, does not necessarily lead to a negative framing of organizations and their activities.

Looking at the CSR frame elements, the effects of CSR fit can be further explored. When organizations' CSR initiatives fit their core business, it is more likely that the organizations are described as substantially changing with regard to its CSR, as perceiving CSR as an investment, and as actively engaging in CSR. All these elements are part of positive CSR frames (strategic idealist and optimist) and therefore indicate a positive representation of organizations and their activities. However, CSR fit increases the likelihood that organizations are described as pursuing their CSR initiatives because of self-interest and stakeholder pressure, and CSR fit decreases the likelihood that an organization is described as perceiving its CSR as a cost.

These observations are largely in line with past research that indicates a positive impact of high CSR fit, as well as with earlier findings in favor of a low CSR fit. It thus supports some of the arguments given to explain such effects. Specifically, the positive effects of CSR fit on frame elements correspond with assumptions that CSR activities with high fit may be perceived to be more structurally embedded within organization (De Jong \& Van der Meer, in press), while the negative effects confirm the potential counter-arguments indicating that CSR activities with low fit may be perceived to be a more deliberate and larger effort (Drumwright, 1996; Ellen et al., 2000).

In all, one can say that these are important new insights, because to date, little research has been conducted on the relationship between CSR fit and media coverage. In their role as an independent monitor of organizations' activities (Zhang \& Swanson, 2006) and as a channel through which the public perceives many societal issues (Andsager \& Smiley, 1998), the media were expected to reflect the organizational behaviors of CSR integration in their coverage. The outcomes of this study indicate that the media reflect organizations' CSR integration not via the tone but via the framing - the aspects included in the news articles - of the media coverage.

\subsection{Practical implications}

Adopting the insights derived from this research to the practice, critical implications for both organizations and news media can be formulated. Since the perception of CSR in the media seems to be mainly positive, simply pursuing CSR can be expected to increase the likelihood of positive media coverage. An even stronger positive effect of CSR can be achieved when an organization pursues CSR initiatives fitting its core business, since CSR fit generally leads to a positive media framing of an organization and its CSR initiatives. However, a lack of CSR fit, will not necessarily result in a negative representation of the organization. In order to maximally benefit from CSR and achieve optimal media coverage, organizations should not only engage in CSR but seek to implement initiatives well integrated into their core business.

\subsection{Limitations}

The cultural background of the newspapers and magazines included in this study was very diverse. While the news articles came from 39 different countries with India representing a remarkable part of the sample (24.8\%), the conceptualization of CSR frames (Tench et al., 2007) was developed based on the perception of British journalists. Since the Anglosaxon cultures significantly differ from, for instance, Southern Asian or Arab cultures (House, Hanges, Javidan, Dorfman, \& Gupta, 2004), the discrepancies between the national-cultural context in which the measured concepts are conceptualized and the national-cultural contexts in which the research was conducted may have affected the results.

\subsection{Suggestions for future research}

The effects of CSR fit on the framing of media coverage offer interesting links for future research. As CSR fit only partly predicted the presentation in the media coverage, it may be assumed that other processes may be prevalent when it comes to media coverage. In order to explore which role CSR fit actually plays for journalists, future research should focus on media professionals. Identifying the mechanisms and factors that play a crucial role in the creation of media coverage on CSR may deliver interesting new insights on how journalists work and deal with the discourse on CSR. Here, Burke and Logsdon (1996) describe some strategy dimensions of CSR that might be relevant for further exploration. Next to centrality, which means “the closeness of fit to the firm's mission and objectives" (Burke \& Logsdon, 1996, p. 407) and is quite similar to CSR fit, they 
further mention voluntarism ("the scope for discretionary decision-making and the lack of externally imposed compliance requirements” (Burke \& Logsdon, 1996, p. 407) and visibility (“observable, recognizable credit by internal and/or external stakeholders for the firm" (Burke \& Logsdon, 1996, p. 407) as CSR strategy dimensions. These concepts represent different strategic aspects when it comes to CSR. By exploring whether and how these impact the media coverage of an organization and its CSR, it could be revealed which strategic aspects are especially important and how an organization should design its CSR strategy in order to achieve a positive representation in the media. Here, it would also be interesting to scrutinize how media professionals perceive their role and responsibilities towards the public when it comes to reporting about CSR.

\section{Acknowledgement}

The authors declare no conflict of interest.

\section{References}

Aguinis, H., \& Glavas, A. (2012). What we know and don't know about corporate social responsibility: A review and research agenda. Journal of Management, 38, 932-968.

Andsager, J., \& Smiley, L. (1998). Evaluating the public information: Shaping news coverage of the silicone implant controversy. Public Relations Review, 24(2), 183-201.

Becker-Olsen, K. L., Cudmore, B. A., \& Hill, R. P. (2006). The impact of perceived corporate social responsibility on consumer behavior. Journal of Business Research, 59, 46-53.

Berger, I. E., Cunningham, H., \& Drumwright, M. E. (2007). Mainstreaming corporate social responsibility: Developing markets for virtue. California Management Review, 49(4), 132-157.

Bloom, P. N., Hoeffler, S., Keller, K. L., \& Meza, C. (2006). How social-cause marketing affects consumer perceptions. MIT Sloan Management Review, 47, 49-55.

Buhr, H., \& Grafström, M. (2007). The making of meaning in the media: The case of corporate social responsibility in the Financial Times, 1988-2003. In F. den, \& L. Hond (Eds.), Managing corporate social responsibility in action: Talking, doing and measuring (pp. 15-32). Ashgate, England: Chippenham.

Burke, \& Logsdon, J. M. (1996). How corporate social responsibility pays off. Long Range Planning, 29(4), 495-502.

De Jong, M. D. T., \& Van der Meer, M. (2016). How does it fit? Exploring the congruence between organizations and their corporate social responsibility (CSR) activities. Journal of Business Ethics, http://dx.doi.org/10.1007/s10551-015-2782-2

De Vreese, C. H., \& Boomgaarden, H. G. (2006). Media effects on public opinion about the enlargement of the European Union. Journal of Common Market Studies, 44(2), 419-436.

Deephouse, D. L. (2000). Media reputation as a strategic resource: An integration of mass communication and resource-based theories. Journal of Management, 26(6), 1091-1112.

Donsbach, W. (2004). Psychology of news decisions: Factors behind journalists' professional behavior. Journalism, 5(2), $131-157$.

Drumwright, M. E. (1996). Company advertising with a social dimension: The role of noneconomic criteria. Journal of Marketing, $60,71-87$.

Du, S., Bhattacharya, C. B., \& Sen, S. (2010). Maximizing business returns to corporate social responsibility (CSR): The role of CSR communication. International Journal of Management Reviews, 12(1), 8-19.

Ellen, P. S., Mohr, L. A., \& Webb, D. J. (2000). Charitable programs and the retailer: Do they mix? Journal of Retailing, $76,393-406$.

Elving, W. J. L. (2013). Scepticism and corporate social responsibility communications: The influence of fit and reputation. Journal of Marketing Communications, 19(4), 1-16.

Entman, R. M. (1993). Framing: Towards clarification of a fractured paradigm. Journal of Communication, 43(4), 51-58.

Gamson, W. A., \& Modigliani, A. (1989). Media discourse and public opinion on nuclear power: A constructionist approach. American Journal of Sociology, $95,1-37$.

Hester, J. B., \& Gibson, R. (2003). The economy and second-level agenda setting: A time series analysis of economic news and public opinion about the economy. Journalism E' Mass Communication Quarterly, 80(1), 73-90.

House, R. J., Hanges, P. J., Javidan, M., Dorfman, P. W., \& Gupta, V. (2004). Leadership, culture, and organizations: The GLOBE study of 62 societies. Beverly Hills, CA: SAGE publications.

Kim, S. H., Carvalho, J. P., \& Cooksey, C. E. (2007). Exploring the effects of negative publicity: News coverage and public perceptions of a university. Public Relations Review, 33, 233-235.

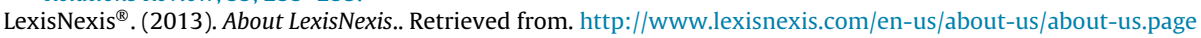

McCombs, M., \& Ghanem, S. I. (2001). The convergence of agenda setting and framing. In S. D. Reese, O. H. Gandy, \& A. E. Grant (Eds.), Framing public life: Perspectives on media and our understanding of the social world (pp. 67-81). Mahweh, NJ: Lawrence Erlbaum Associates Inc.

Miller, M. M., \& Riechert, B. P. (2001). Frame mapping: A quantitative method for investigating issues in the public sphere. In M. D. West (Ed.), Applications of computer content analysis (pp. 61-75). Westport, CT: Greenwood Publishing Group.

Price, V., Tewksbury, D., \& Powers, E. (1997). Switching trains of thought: The impact of news frames on readers' cognitive responses. Communication Research, 24(5), 481-506.

Stanaland, A. J. S., Lwin, M. O., \& Murphy, P. E. (2011). Consumer perceptions of the antecedents and consequences of corporate social responsibility. Journal of Business Ethics, 102, 47-55.

Tench, R., Bowd, R., \& Jones, B. (2007). Perceptions and perspectives: Corporate social responsibility and the media. Journal of Communication Management, $11(4), 348-370$.

Wang, A. (2007). Priming, framing and position on corporate social responsibility. Journal of Public Relations Research, $10(2), 123-145$.

Yuan, W., Bao, Y., \& Verbeke, A. (2011). Integrating CSR initiatives in business: An organizing framework. Journal of Business Ethics, $101,75-92$.

Zhang, J., \& Swanson, D. (2006). Analysis of news media's representation of corporate social responsibility. Public Relations Quarterly, 51 (2), 13-17. 